Article

\title{
Development and Evaluation of qPCR Detection Method and Zn-MgO/Alginate Active Packaging for Controlling Listeria monocytogenes Contamination in Cold-Smoked Salmon
}

\author{
Priya Vizzini ${ }^{1}$, Elena Beltrame ${ }^{1}$, Valentina Zanet ${ }^{1}$, Jasmina Vidic ${ }^{2, *}$ and Marisa Manzano ${ }^{1, *}$ \\ 1 Department of Agriculture Food Environmental and Animal Sciences, University of Udine, 33100 Udine, \\ Italy; vizzini.priya@spes.uniud.it (P.V.); beltrame.elena@spes.uniud.it (E.B.); \\ zanet.valentina@spes.uniud.it (V.Z.) \\ 2 Micalis Institute, INRAE, AgroParisTech, Université Paris-Saclay, 78350 Jouy-en-Josas, France \\ * Correspondence: jasmina.vidic@inrae.fr (J.V.); marisa.manzano@uniud.it (M.M.); \\ Tel.: +33-134652737 (J.V.); +39-0432558127 (M.M.)
}

Received: 25 August 2020; Accepted: 21 September 2020; Published: 24 September 2020

check for updates

\begin{abstract}
To answer to food industry requests to monitor the presence of L. monocytogenes in cold-smoked salmon samples and to extend their shelf-life, a qPCR protocol for the detection of L. monocytogenes, and an antibacterial active packaging reinforced with zinc magnesium oxide nanoparticles ( $\mathrm{Zn}-\mathrm{MgO} \mathrm{NPs}$ ) were developed. The qPCR allowed the sensitive and easy detection of L. monocytogenes in naturally contaminated samples, with specificity in full agreement with the standard methods. The halo diffusion study indicated a high antibacterial efficiency of $1 \mathrm{mg} / \mathrm{mL}$ $\mathrm{Zn}-\mathrm{MgO}$ NPs against L. monocytogenes, while the flow cytometry showed only moderate cytotoxicity of the nanoparticles towards mammalian cells at a concentration above $1 \mathrm{mg} / \mathrm{mL}$. Thus, the novel active packaging was developed by using $1 \mathrm{mg} / \mathrm{mL}$ of $\mathrm{Zn}-\mathrm{MgO}$ NPs to reinforce the alginate film. Cold-smoked salmon samples inoculated with L. monocytogenes and air-packed with the $\mathrm{Zn}-\mathrm{MgO}$ NPs-alginate nanobiocomposite film showed no bacterial proliferation at $4{ }^{\circ} \mathrm{C}$ during 4 days. In the same condition, L. monocytogenes growth in control contaminated samples packed with alginate film alone. Our results suggest that $\mathrm{Zn}-\mathrm{MgO}$ nanoparticles can extend the shelf-life of cold-smoked salmon samples.
\end{abstract}

Keywords: Listeria monocytogenes; cold-smoked salmon; $\mathrm{Zn}-\mathrm{MgO}$ nanoparticles; active packaging; qPCR

\section{Introduction}

Foodborne diseases are responsible worldwide for millions of illnesses and thousands of hospitalizations that can be fatal, which demonstrates the urge to develop novel technologies to improve food safety. As such, rapid and accurate pathogen detection in foodstuffs together with advanced antibacterial food packaging play an important role in providing safe and fresh-like foods with longer shelf life. This is particularly true for ready-to-eat (RTE) foods that are associated with serious microbial risks because they are more susceptible to contamination by spoilage microorganisms and pathogens such as Listeria monocytogenes. Notably, RTE meat and fish products that undergo long-term refrigerated storage are considered as high-risk for L. monocytogenes.

L. monocytogenes is a short, motile, Gram-positive, non-spore-forming rod, invasive pathogen responsible for listeriosis, a foodborne disease associated with $30 \%$ cases of deaths [1-3]. L. monocytogenes possesses great resistance to low temperature, acidification, and to various antimicrobial agents used in food processing or equipment cleaning. For instance, bacteria can multiply and grow under salt 
concentrations up to $10 \%$ and at refrigeration temperatures (in the range of $4{ }^{\circ} \mathrm{C}$ to $8{ }^{\circ} \mathrm{C}$ ) which makes it capable to overcome the various procedures set to limit microbial growth $[4,5]$. In addition, L. monocytogenes is one of the major causes of food recalls, causing large economic losses [1,6-9].

The difficulty to detect this bacterium during food-processing has led the food industry to search for novel, easy and accurate methods that would enable routine microbiological screening for L. monocytogenes food contamination [10,11]. Traditional plate count methods, such as the ISO standard (11290: 2017) method or its equivalents, require a long time for the analysis [12,13]. These methods consist of two enrichment and selective steps followed by bacterial isolation on differential media and biochemical tests for identification [14]. Thus, culture-independent methods for the rapid detection of Listeria, such as PCR-based methods (end-point PCR, PCR-RE, qPCR), are needed to reduce the analysis time and improve routine food control [10,14-19].

An inhibition or retardation of L. monocytogenes growth in RTE foods is also necessary because this pathogen can contaminate food products after the preparation step (during processing, storing and distribution) and continue to grow during shelf life which potentially leads to food spoilage and risk of foodborne diseases. One innovative way to inhibit $L$. monocytogenes growth in food during long-term storage is the use of active packaging (1935/2004/EC, 450/2009/EC). An active antimicrobial packaging targets specific microorganisms and controls the microbial population by releasing biocide substances onto or around the food, which assures food safety, extends shelf life and delays or prevents spoilage [20]. Metal oxide nanoparticles (NPs) are attractive biocide materials for active packaging because they are stable and highly efficient against various pathogenic bacteria [21,22]. Among the metal oxide NPs, zinc oxide ( $\mathrm{ZnO}) \mathrm{NPs}$ are being used industrially for many applications due to its strong antimicrobial effect on a broad spectrum of microorganisms and its easy incorporation into different matrices [23]. Moreover, $\mathrm{ZnO}$ is currently listed by FDA (U.S. Food and Drug Administration) as a generally recognized as safe material [24]. However, in vitro and in vivo studies in animal and human models indicated that nanosized $\mathrm{ZnO}$ could also be potentially hazardous due to its high reactivity $[25,26]$. In contrast, mixed $\mathrm{Zn}-\mathrm{MgO}$ nanomaterials, which are produced through the association of zinc with highly biocompatible magnesium oxide (MgO) NPs, retained a strong antibacterial effect toward Gram-positive bacteria similar to ZnO NPs and was safe for mammalian cells like the nano-MgO [26-28]. In consequence, incorporation of mixed $\mathrm{Zn}-\mathrm{MgO}$ NPs into an active packaging instead of pure nano- $\mathrm{ZnO}$ seems to be more suitable.

The aim of this work was to develop a fast, specific and easy qPCR protocol to test for the presence of L. monocytogenes in sliced cold-smoked salmon (CSS) samples, and to evaluate the utilization of $\mathrm{Zn}-\mathrm{MgO}$ NPs to create an active film packaging in order to prolong CSS shelf life. CSS was chosen as a model food because it is distributed as an RTE food that does not undergo heat treatments before being consumed and is therefore considered of high risk of L. monocytogenes contamination [6-9].

\section{Materials and Methods}

\subsection{Materials and Reagents}

All media and reagents for microbiological analyses were purchased from Oxoid (Milan, Italy). Triton X-100, SDS, $\mathrm{NaCl}$, Tris-HCl, sodium alginate, and EDTA were purchased from Sigma-Aldrich (Milan, Italy).

The AmpliTaq ${ }^{\circledR}$ Buffer 10X, AmpliTaq ${ }^{\circledR}$ DNA Polymerase, PCR Nucleotide Mix $10 \mathrm{mM}$ and $\mathrm{MgCl}_{2} 25 \mathrm{mM}$ were purchased from Applied Biosystems (Milan, Italy). The SsoFast ${ }^{\mathrm{TM}}$ EvaGreen ${ }^{\circledR}$ kit (Bio-rad, Irvine, CA, USA) and $\mathrm{MgCl}_{2} 25 \mathrm{mM}$ (Applied Biosystems, Milan, Italy) were employed to perform qPCR tests using the Rotor-Gene $\mathrm{Q}$ (Qiagen, Milan, Italy). Zn-MgO nanoparticles $\left(\mathrm{Mg}_{1-x} \mathrm{Zn}_{x} \mathrm{O}\right.$, $x=0.85$ ), with an average size from 5 to $10 \mathrm{~nm}$, used in this work were a kind gift from Slavica Stankic (INSP, France). They were prepared and characterized as described previously [28,29].

The ready-to-eat (RTE) food corresponds to 16 samples of $100 \mathrm{~g}$ of sliced cold-smoked salmon (Salmo salar), (CSS) that were purchased from local supermarkets and were processed from fresh never 
frozen fish. All the CSS samples had Aw values between 0.983 and 0.964 , a $\mathrm{pH}$ about 6, and were preservative-free and vacuum-packaged. The reference bacteria used in this work are listed in Table 1.

Table 1. List of the microorganisms used.

\begin{tabular}{|c|c|c|}
\hline & Microorganism & Reference Code \\
\hline \multirow{4}{*}{ Positive controls } & Listeria monocytogenes $1 / 2 \mathrm{c}$ & * ATCC 7644 \\
\hline & Listeria monocytogenes $1 / 2 \mathrm{a}$ & ${ }^{\circ}$ DISTAM \\
\hline & Listeria monocytogenes $1 / 2 b$ & ${ }^{\circ}$ DISTAM \\
\hline & Listeria monocytogenes $4 \mathrm{~b}$ & \# DSMZ 15675 \\
\hline \multirow{12}{*}{ Negative controls } & Listeria innocua & \# DSMZ 20649 \\
\hline & Listeria ivanovii & $\S \mathrm{DI} 4 \mathrm{~A}$ \\
\hline & Salmonella enterica & \# DSMZ 9145 \\
\hline & Enterobacter spp. & $\S \mathrm{DI} 4 \mathrm{~A}$ \\
\hline & Escherichia coli & $\S \mathrm{DI} 4 \mathrm{~A}$ \\
\hline & Bacillus cereus & \# DSMZ 2301 \\
\hline & Campylobacter jejuni & \# DSMZ 49943 \\
\hline & Lactobacillus plantarum & ${ }^{*}$ ATCC BAA-793 \\
\hline & Lactobacillus rhamnosus & * ATCC 53103 \\
\hline & Lactobacillus paracasei & \# DSMZ 5622 \\
\hline & Lactobacillus brevis & \# DSMZ 20054 \\
\hline & Bacillus subtilis & \# DSMZ 4181 \\
\hline
\end{tabular}

* ATCC: American Type Culture Collection (Manassas, VA, USA); ${ }^{\circ}$ DISTAM: Dipartimento di Scienze e Tecnologie Alimentari e Microbiologiche (Milan, Italy); \# DSMZ: Deutsche Sammlung von Mikroorganism und Zellkulturen $\mathrm{GmbH}$ (Braunschweigh, Germany); § DI4A: Dipartimento di Scienze AgraroAlimentari, Ambientali e Animali dell'Università degli Studi di Udine (Udine, Italy).

\subsection{Primer Design}

A specific reverse primer (MarB) was designed using the "Multiple sequence alignment with hierarchical clustering" [30] and coupled to the Mar1 fw primer [15] for the specific detection of L. monocytogenes in food samples using qPCR technique. The couple of primers that were expected to produce an amplicon of $160 \mathrm{bp}$ were tested in silico by confirming the production of the expected $160 \mathrm{bp}$ amplicon with OligoAnalyzer 3.1 [31] and AmplifX 1.7.0 [32], before being used on DNAs extracted from the bacteria listed in Table 1.

\subsection{PCR and qPCR Analyses}

DNAs were extracted from the bacteria listed in Table 1 using the protocol described by Comi et al. [33] with some modifications. Briefly, $2 \mathrm{~mL}$ of homogenates were collected from the Stomacher bags with Bolton broth, centrifuged for $10 \mathrm{~min}$ at 13,000 rpm, and the pellet suspended in $200 \mu \mathrm{L}$ breaking buffer (2\% Triton X-100, 1\% SDS, $100 \mathrm{mM} \mathrm{NaCl}, 10 \mathrm{mM}$ Tris-HCl, 1 mM EDTA pH 8; Sigma-Aldrich) before being subjected to DNA extraction.

DNAs were used in an end-point PCR to verify the specificity and sensitivity of the primers and in qPCR to build the standard curve. The PCR protocol adopted was as follows: $5 \mu \mathrm{L}$ AmpliTaq ${ }^{\circledR}$ Buffer 10X (Applied Biosystems, Milan, Italy), $1 \mu \mathrm{L} \mathrm{MgCl}_{2} 25 \mathrm{mM}$ (Applied Biosystems), $1 \mu \mathrm{L}$ PCR Nucleotide Mix $10 \mathrm{mM}$ each (Applied Biosystems), $1 \mu \mathrm{L}$ of each primer (Mar1 and MarB at $10 \mu \mathrm{M}$ ), $0.25 \mu \mathrm{L}$ AmpliTaq ${ }^{\circledR}$ DNA Polymerase 5 units/ $\mu \mathrm{L}$ (Applied Biosystems) in a final reaction volume of $50 \mu \mathrm{L}$ including $1 \mu \mathrm{L}$ of template DNA at $100 \mathrm{ng} / \mu \mathrm{L}$. A no-template control called NTC was used to ensure the absence of contamination. Thermal cycler conditions consisted of $95^{\circ} \mathrm{C}$ denaturation for 
$5 \mathrm{~min}, 35$ cycles of $95^{\circ} \mathrm{C}$ for $1 \mathrm{~min}, 48^{\circ} \mathrm{C}$ for $45 \mathrm{~s}, 72{ }^{\circ} \mathrm{C}$ for $30 \mathrm{~s}$ and a final extension at $72{ }^{\circ} \mathrm{C}$ for $7 \mathrm{~min}$ in a Thermal Cycler (C1000 Touch ${ }^{\mathrm{TM}}$; Bio-rad, Hercules, CA, USA).

A qPCR using Mar1 and MarB primers and decimal dilutions (from $100 \mathrm{ng} / \mu \mathrm{L}$ to $1 \mathrm{fg} / \mu \mathrm{L}$ ) of the DNA of L. monocytogenes $1 / 2 \mathrm{~b}$ DISTAM was used to build a standard curve by relating fluorescence with threshold cycle $(\mathrm{Ct})$. The threshold limit setting was performed in automatic mode using SsoFast ${ }^{\mathrm{TM}}$ EvaGreen ${ }^{\circledR}$ kit (Bio-rad, Milan, Italy) according to the manufacturer's instructions. The reaction mixture contained the following reagents: $10 \mu \mathrm{L}$ SsoFast ${ }^{\mathrm{TM}}$ EvaGreen ${ }^{\circledR}$ Supermix $2 \mathrm{X}$ (Bio-rad), $1 \mu \mathrm{L}$ $\mathrm{MgCl}_{2} 25 \mathrm{mM}$ (Applied Biosystems, Monza, Italy), $1 \mu \mathrm{L}$ of each primer at $10 \mu \mathrm{M}$ in a final reaction volume of $20 \mu \mathrm{L}(13 \mu \mathrm{L}$ of reaction mixture, $6 \mu \mathrm{L}$ of nuclease-free water and $1 \mu \mathrm{L}$ of template DNA at various concentrations). For each assay, a positive control using L. monocytogenes $1 / 2 \mathrm{~b}$ DISTAM, negative control using L. innocua DSMZ 20649, and an NTC ( $1 \mu \mathrm{L}$ water instead of DNA) were included. The thermal program applied consisted of $98^{\circ} \mathrm{C}$ hot-start activation for $2 \mathrm{~min}, 40$ cycles of $98{ }^{\circ} \mathrm{C}$ denaturation for $5 \mathrm{~s}$ and $60^{\circ} \mathrm{C}$ annealing/extension for $20 \mathrm{~s}$, followed by melting temperature analysis performed by gradually increasing the temperature from 60 to $95^{\circ} \mathrm{C}\left(+0.5^{\circ} \mathrm{C} / 5 \mathrm{~s}\right)$ in the Rotor-Gene $\mathrm{Q}$ (Qiagen, Milan, Italy).

\subsection{Plate Count Analyses of Cold-Smoked Salmon Samples}

Sixteen samples ( $10 \mathrm{~g}$ each) of sliced salmon were added to a sterile Stomacher bag containing $40 \mathrm{~mL}$ of saline-peptone water $(8 \mathrm{~g} / \mathrm{L} \mathrm{NaCl}, 1 \mathrm{~g} / \mathrm{L}$ bacteriological peptone; Oxoid), homogenate in a Stomacher (PBI, Milan, Italy) for $30 \mathrm{~s}$ and used for plate count bacterial enumeration. Eight samples were analyzed immediately after purchasing (CSS 1-8 $t_{0}$ ) and eight others were incubated at $+4{ }^{\circ} \mathrm{C}$ and analyzed after 28 days (close to expiration date) (CSS 1-8 $t_{28}$ ). The plate count method was used for the determination of: (i) total viable count on TSA, (Tryptone Soya Agar, Oxoid, Milan, Italy) incubated at $30{ }^{\circ} \mathrm{C}$ for $48 \mathrm{~h}$; (ii) Enterobacteriaceae, count on VRBG agar (Oxoid) incubated at $37^{\circ} \mathrm{C}$ for $24 \mathrm{~h}$; (iii) lactic acid bacteria (LAB) count on MRS (Oxoid) incubated at $30^{\circ} \mathrm{C}$ for $48 \mathrm{~h}$ in Anaero-Jar $2.5 \mathrm{~L}$ (Oxoid) with microaerophilic conditions; (iv) yeasts and molds were enumerated on Malt Extract Agar (Oxoid) with $10 \mu \mathrm{g} / \mathrm{mL}$ of tetracycline (Sigma-Aldrich) incubated at $30^{\circ} \mathrm{C}$ for $48 \mathrm{~h}$.

For this, $10 \mathrm{~g}$ of the samples were transferred into a filter sterile Stomacher bag containing $40 \mathrm{~mL}$, and were mixed in a Stomacher (PBI, Milan, Italy) for $30 \mathrm{~s}$. The homogenization solutions were used for plate count bacterial enumeration and for DNA extraction. The Listeria Precis ${ }^{\mathrm{TM}}$ method (NF Validation, 2013, [34]) and molecular methods were used to detect the presence of Listeria monocytogenes. Twenty-five $\mathrm{g}$ of CSS samples were transferred into a filter sterile Stomacher bag, added with $225 \mathrm{~mL}$ of ONE Broth-Listeria (Oxoid) mixed for $30 \mathrm{~s}$ in a Stomacher (PBI) and incubated at $30{ }^{\circ} \mathrm{C}$ for $24 \mathrm{~h}$.

The selective isolation of L. monocytogenes was performed according to Listeria Precis ${ }^{\mathrm{TM}}$ method. Briefly, $25 \mathrm{~g}$ of sample is enriched for $24 \mathrm{~h} \pm 2 \mathrm{~h}$ at $30^{\circ} \mathrm{C}$ in $225 \mathrm{~mL}$ ONE Broth-Listeria (Oxoid) and after $10 \mu \mathrm{L}$ are plated by streaking on Brilliance Listeria Agar. After $22-26 \mathrm{~h}$ at $37^{\circ} \mathrm{C}$ incubation blue/green colonies with halos are confirmed using the O.B.I.S. mono test. Colonies which do not develop deep purple color are confirmed L. monocytogenes. Presumed colonies of L. monocytogenes, were tested with the O.B.I.S. mono test (Oxoid), and the confirmed colonies were subjected to DNA extraction (DNAIsolates). DNA was also extracted from One Broth solutions immediately (DNA-OB 1-8 $t_{0}$ ) and after $24 \mathrm{~h}$ (DNA-OB 1-8 $t_{24}$ ) according to Cecchini et al. [35].

\subsection{Artificially Contamination (AC) of Cold-Smoked Samples}

Ten grams of CSS samples were exposed with L. monocytogenes $1 / 2 \mathrm{~b}$ DISTAM, at concentrations of 10 cells $/ \mathrm{g}\left(\mathrm{AC}_{10}\right), 10^{2}$ cells/g $\left(\mathrm{AC}_{100}\right)$ and $10^{3} \mathrm{cells} / \mathrm{g}\left(\mathrm{AC}_{1000}\right)$ and kept at $30^{\circ} \mathrm{C}$ for $30 \mathrm{~min}$ to allow the inoculum to soak into the food. After the contamination, samples were incubated at $30^{\circ} \mathrm{C}$ for $24 \mathrm{~h}$ in 1:10 ONE Broth-Listeria (Oxoid), before being processed for DNA extraction (for qPCR analyses) and analyzed with the Listeria Precis ${ }^{\mathrm{TM}}$ method. 


\subsection{Listeria monocytogenes Inhibition Test Using Zn-MgO Nanoparticles}

To verify the possible utilization of $\mathrm{Zn}-\mathrm{MgO}$ NPs for the production of an active film intended to prolong the shelf life of the CSS samples, the antibacterial effect of the Zn-MgO NPs was tested on L. monocytogenes using the haloes test. An amount of $100 \mu \mathrm{L}$ of the microbial suspension of L. monocytogenes grown in BHI broth until about $5 \times 10^{6}$ cells $/ \mathrm{mL}$ (a concentration corresponding to $0.5 \mathrm{McFarland}$ ) was spread onto the surface of BHI agar plates. Subsequently, $5 \mathrm{~mm}$ wells were created [36] into the agar and filled with $20 \mu \mathrm{L}$ suspensions of $\mathrm{Zn}-\mathrm{MgO}$ at $0.1 \mathrm{mg} / \mathrm{mL}, 0.5 \mathrm{mg} / \mathrm{mL}$, and $1 \mathrm{mg} / \mathrm{mL}$. Negative control of $20 \mu \mathrm{L}$ water $(0 \mathrm{mg} / \mathrm{mL} \mathrm{Zn-MgO})$ was used. The plates were incubated at $37^{\circ} \mathrm{C}$ for $24 \mathrm{~h}$, the diameters of the zones of inhibition (haloes) were measured using a ruler. Values were expressed in mm diameter, mean \pm SD of at least three independent experiments.

\subsection{Cytotoxicity Test on Mammalian Cell Cultures and FACS Measurements}

Human macrophage-like cells U937 and differentiated human promyelocytic leukemia cell line HL-60 were used to estimate the cytotoxicity of $\mathrm{Zn}-\mathrm{MgO}$ nanoparticles. Cells were cultured in RMPI 1640 medium (Lonza, Verviers, Belgium) supplemented with $10 \%$ fetal bovine serum, $2 \mathrm{~mm}$ l-glutamine, $100 \mathrm{IU} / \mathrm{mL}$ of penicillin, and $100 \mu \mathrm{g} / \mathrm{mL}$ of streptomycin [26,37], at $37^{\circ} \mathrm{C}$ in a $5 \% \mathrm{CO}_{2}$ incubator. After incubation with the NPs at $0 \mathrm{mg} / \mathrm{mL}, 0.1 \mathrm{mg} / \mathrm{mL}$ and $1 \mathrm{mg} / \mathrm{mL}$, the cells were trypsinized to detach them from the culture vessel and concentrated by centrifugation $(5 \mathrm{~min}$ at $3000 \times g)$. The collected cells were washed twice in PBS, resuspended in minimum culture medium containing acridine orange $(0.1 \mu \mathrm{g} / \mathrm{mL})$ and incubated in the dark, at $37^{\circ} \mathrm{C}$ for $10 \mathrm{~min}$. The stained cells were washed with PBS and fixed with $3.2 \%$ paraformaldehyde in PBS for $30 \mathrm{~min}$. Flow cytometry analysis was performed using Becton FACSCalibur (Dickinson and Company, Franklin Lakes, NJ, USA) with the $488 \mathrm{~nm}$ laser line and FL-1 channel to quantify cell viability. Each analysis was done on $5 \times 10^{4}$ cells in triplicate. Results are presented as mean \pm SD.

\subsection{Active Film Packaging Formation and Challenge Test Protocol}

Active films with antibacterial activity prepared from $\mathrm{Zn}-\mathrm{MgO}$ powder were produced following a modified procedure from Akbar and Kumar (2014) [38]. Briefly, $1.167 \mathrm{~g}$ of sodium alginate were gently mixed with $50 \mathrm{~mL}$ of deionized water using a stirrer at room temperature for $6 \mathrm{~h}$. A volume of $1.5 \mathrm{~mL}$ calcium chloride ( $5 \% \mathrm{w} / \mathrm{v})$ and $1.5 \mathrm{~mL}$ glycerol (100\%) were added to the $50 \mathrm{~mL}$ alginate solution and mixed for $10 \mathrm{~min}$. Then, $55 \mathrm{mg}$ of $\mathrm{Zn}-\mathrm{MgO}$ powder was added to the sodium alginate and mixed for $5 \mathrm{~min}$. The obtained solution $(1 \mathrm{mg} / \mathrm{mL})$ was poured into a Petri dish $(60 \mathrm{~mm}$ diameter; Steriplan ${ }^{\circledR}$ Petri dish, DURAN ${ }^{\circledR}$ ) and evenly spread with the help of a slight rotation of the plate. Plates were incubated at $50{ }^{\circ} \mathrm{C}$ for $12 \mathrm{~h}$, subsequently wet with $10 \mathrm{~mL}$ calcium chloride (5\%) for $10 \mathrm{~min}$ and washed three times with distilled water before being dried at $50{ }^{\circ} \mathrm{C}$ for $1 \mathrm{~h}$. A film without the addition of $\mathrm{Zn}-\mathrm{MgO}$ was used as a negative control. Films were sterilized under ultraviolet radiation for $2 \mathrm{~h}$ to eliminate any surface contamination before their utilization.

Ten pieces of $1.5 \mathrm{~cm} \times 1.5 \mathrm{~cm}\left(2.25 \mathrm{~cm}^{2}\right)$ of CSS samples were subjected to a UV light treatment of $2 \mathrm{~h}$ (for surface sterilization) before utilization. Two pieces were immediately analyzed for the presence of L. monocytogenes, while eight pieces were inoculated with $100 \mu \mathrm{L}$ of L. monocytogenes overnight culture diluted at $1.3 \times 10^{9} \mathrm{CFU} / \mathrm{mL}$ to obtain an inoculum of $6.0 \times 10^{2} \mathrm{CFU} / \mathrm{cm}^{2}$. Four inoculated samples were packed with the active alginate film (with the addition of NPs) and four with the standard alginate film (no addition of NPs). All inoculated samples were stored at $+4{ }^{\circ} \mathrm{C}$ for 4 days (typical smoked salmon storage temperature) before being analyzed. Packaging and storing were performed under aerobic conditions. Data are expressed as (mean $\pm \mathrm{SD}$ ) $\mathrm{CFU} / \mathrm{cm}^{2}$. 


\section{Results and Discussion}

\subsection{Plate Count Results on Commercial CSS RTE CCS and Artificially Contaminated CSS Samples}

As expected, the AFNOR Listeria Precis ${ }^{\mathrm{TM}}$ method was able to detect L. monocytogenes in the artificially contaminated CSS samples $\left(\mathrm{AC}_{10}, \mathrm{AC}_{100}, \mathrm{AC}_{1000}\right)$ at the three concentrations of 10,100 and 1000 cells/g used in the assay. Thereafter, the microbiological load of the commercial RTE CSS immediately after purchasing and after 28 days of storage at $4{ }^{\circ} \mathrm{C}$ was obtained by using the plate count method immediately after purchasing and after 28 days of storage at $4{ }^{\circ} \mathrm{C}$ and is reported in Table 2. The microbiological data obtained were in agreement with the literature data for safe CSS $[39,40]$. After 28 days, only one out of the 16 cold-smoked salmon samples (CSS5t 28 ) was positive to L. monocytogenes when analyzed with the AFNOR validated Listeria Precis ${ }^{\mathrm{TM}}$ method. This finding is in accordance with the low prevalence of the pathogen reported in the literature for a high sample size $[6,7,41]$. Moreover, all isolates on Brilliance Listeria agar were tested for L. monocytogenes with the O.B.I.S. method, before being tested by PCR.

Table 2. Plate count data of cold-smoked salmon (CSS) samples expressed as Colony Forming Unit $(\mathrm{CFU}) /$ g. $t_{0}$ : analysis at the purchasing; $t_{28}$ : analysis after 28 days incubation at $+4{ }^{\circ} \mathrm{C}$.

\begin{tabular}{|c|c|c|c|c|}
\hline Samples & Total Viable & Lactic Acid & Enterobacteriaceae & Yeasts \\
\hline & Count & Bacteria & & \\
\hline $\mathrm{CSS} 1 t_{0}$ & 6.25 & 4.94 & $<0.7$ & $<1.40$ \\
\hline $\mathrm{CSS} 2 t_{0}$ & 5.38 & 4.94 & $<4.34$ & 4.59 \\
\hline $\mathrm{CSS}_{3} t_{0}$ & 5.78 & $<4.34$ & 1.65 & 2.89 \\
\hline $\mathrm{CSS} 4 t_{0}$ & 4.40 & $<4.34$ & $<0.7$ & 1.57 \\
\hline $\mathrm{CSS}_{5} t_{0}$ & 6.08 & 4.80 & 3.65 & 3.25 \\
\hline $\mathrm{CSS}_{6} t_{0}$ & 5.23 & 4.87 & $<0.7$ & 1.40 \\
\hline $\mathrm{CSS} \mathrm{t}_{0}$ & 8.11 & 6.98 & $<0.7$ & 4.77 \\
\hline $\mathrm{CSS} 8 t_{0}$ & 5.86 & 5 & $<0.7$ & 4.50 \\
\hline $\mathrm{CSS}_{1} t_{28}$ & 5.38 & $<4.40$ & $<0.7$ & 2.84 \\
\hline $\mathrm{CSS} 2 t_{28}$ & 7.84 & 7.18 & 4.30 & 5.99 \\
\hline $\mathrm{CSS}_{3} t_{28}$ & 5.91 & 4.87 & $<0.7$ & 3.84 \\
\hline $\mathrm{CSS}_{28} \mathrm{t}_{28}$ & 6.50 & 5.95 & $<0.7$ & 5.75 \\
\hline $\mathrm{CSS}_{2} t_{28}$ & 6.23 & $<4.38$ & 1.72 & 2.41 \\
\hline $\mathrm{CSS}_{28}$ & 6.11 & 5.96 & 2.36 & $<1.40$ \\
\hline $\mathrm{CSS}_{28}$ & 8.25 & 7.72 & $<0.7$ & 5.18 \\
\hline $\mathrm{CSS}_{2} \mathrm{t}_{28}$ & 6.08 & $<4.34$ & $<0.7$ & 4.76 \\
\hline
\end{tabular}

\subsection{Specificity and Sensitivity of the Primers with PCR and $q P C R$}

The PCR carried out on the DNA extracted from the reference strains, listed in Table 1, demonstrated the specificity of the primers Mar1-MarB. The expected amplicon of $160 \mathrm{bp}$ was only produced by strains of L. monocytogenes, while no DNA bands were visible for other Listeria species or other bacterial genus tested (Figure 1a). The sensitivity of the primers Mar1-MarB with the endpoint method used was of $1 \mathrm{pg} / \mu \mathrm{L}$ DNA of L. monocytogenes as shown in Figure 1b. The good result of Mar1-MarB primers on specificity obtained with endpoint PCR justified their use in a quantitative PCR. 
a)

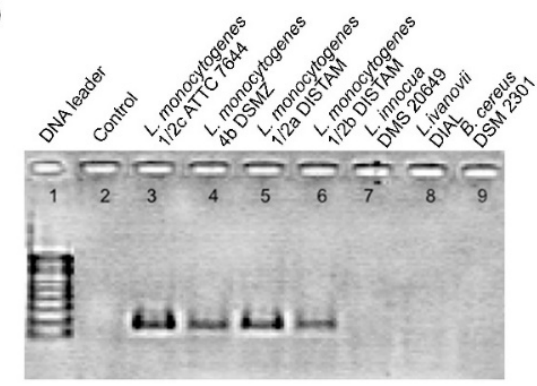

b)

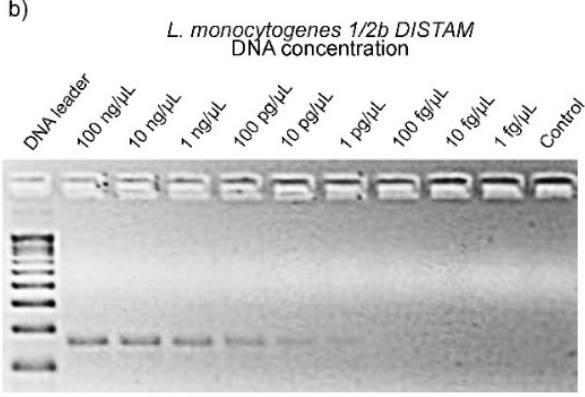

Figure 1. (a) PCR specificity with primers Mar1-MarB using positive and negatives controls. Line 1: 100 bp DNA ladder (Promega, Milan, Italy); line 2: NCT (no template control); line 3: L. monocytogenes 1/2c ATCC 7644; line 4: L. monocytogenes 4b DSMZ 15675; line 5: L. monocytogenes 1/2a DISTAM; line 6: L. monocytogenes 1/2b DISTAM; line 7: L. innocua DSM 20649; line 8: L. ivanovii DI4A; line 9: Bacillus cereus DSM 2301. (b) PCR sensitivity with Mar1-MarB using serial dilution of DNA of L. monocytogenes 1/2b DISTAM. Line 1: $100 \mathrm{bp}$ DNA ladder (Promega, Italy); lines 2: $100 \mathrm{ng} / \mu \mathrm{L}$ DNA; line 3: $10 \mathrm{ng} / \mu \mathrm{L}$ DNA; line 4: $1 \mathrm{ng} / \mu \mathrm{L}$ DNA; line 5: $100 \mathrm{pg} / \mu \mathrm{L}$ DNA; line 6: $10 \mathrm{pg} / \mu \mathrm{L}$ DNA; line 7: $1 \mathrm{pg} / \mu \mathrm{L}$ DNA; line 8: $100 \mathrm{fg} / \mu \mathrm{L}$ DNA; line 9: $10 \mathrm{fg} / \mu \mathrm{L}$ DNA; line 10: $1 \mathrm{fg} / \mu \mathrm{L}$ DNA; line 11: NCT (no template control).

The standard curve of the qPCR obtained with primers Mar1-MarB showed a $R^{2}=0.997$, a slope of -2.956 , and an efficiency $=-1+10(-1 /$ slope $)(Y=-2975 \times \log ($ conc $)+22.278)$. The efficiency value of $117 \%$ was calculated based on the obtained threshold cycles (Ct). In qPCR analysis, only efficiencies ranging from $90 \%$ to $110 \%$ are considered optimal. However, we can consider our efficiency value as good because it is similar to another efficiency that has been also reported as good during the quantification of various pathogens [42,43].

No positive samples for L. monocytogenes were detected using DNA extracted at $t_{0}$ (DNA-OB $t_{0}$ samples) in 16 CSS samples with qPCR absolute quantitation using the DNA extracted after enrichment in ONE Broth-Listeria. Analysis of DNA extracted at $t_{28}$ (DNA-OB $t_{28}$ samples) indicated that only the sample CSS5t $t_{28}$ was positive to L. monocytogenes (Ct 25.61). The obtained results were in full agreement with those reported using AFNOR validated Listeria Precis ${ }^{\mathrm{TM}}$ method presented above. L. monocytogenes was quantified in artificially contaminated (AC) samples, after $24 \mathrm{~h}$ of enrichment step in ONE Broth-Listeria, to confirm the capability of the protocol to detect low bacterial amounts. The $C_{t}$ value of $\mathrm{AC}_{10}, \mathrm{AC}_{100}$ and $\mathrm{AC}_{1000}$ was $23.12,21.50$ and 19.85, respectively. The correlation between $C_{t}$ values and bacterial concentration in AC samples enabled the estimation of L. monocytogenes in the naturally contaminated sample CSS5 $t_{28}$ to concentration as low as $52.37 \mathrm{pg} / \mu \mathrm{L}$, i.e., around $10 \mathrm{cells} / \mathrm{g}$. This indicated the capability of the new qPCR procedure to detect a very low amount of the pathogen in a naturally contaminated sample.

\subsection{Listeria monocytogenes Plate Inhibition Test}

Before starting the elaboration of an active film containing $\mathrm{Zn}-\mathrm{MgO}$, the antibacterial effect of the nanoparticles toward L. monocytogenes was evaluated by the haloes test. The test was considered 
negative if the halo had the diameter of the well size $(5 \mathrm{~mm})$ and it was considered positive when its diameter was bigger than $5 \mathrm{~mm}$. The negative control corresponding to the water solution containing no nanoparticle showed no halo. The absence of inhibition haloes was also observed for the solutions containing 0.1 and $0.5 \mathrm{mg} / \mathrm{mL} \mathrm{Zn}-\mathrm{MgO}$. On the contrary, the solution of $\mathrm{Zn}-\mathrm{MgO}$ at $1 \mathrm{mg} / \mathrm{mL}$ produced haloes of $8 \pm 0.1 \mathrm{~mm}$. This finding suggested the antimicrobial activity of $\mathrm{Zn}-\mathrm{MgO}$ at $1 \mathrm{mg} / \mathrm{mL}$ against L. monocytogenes. Subsequently, the concentration of $1 \mathrm{mg} / \mathrm{mL} \mathrm{Zn-MgO}$ was used to reinforce the alginate packaging films.

\section{4. $\mathrm{Zn}-\mathrm{MgO}$ Cytotoxicity}

To verify whether $\mathrm{Zn}-\mathrm{MgO}$ is toxic towards mammalian cells, U937, and HL-60 cells were incubated with the nanoparticles at different concentrations and analyzed by the acridine orange assay and flow cytometry (treated cells). In controls, cells were incubated with the medium without nanoparticles (untreated cells). After incubation, cells were stained by the acridine orange dye, which can enter mammalian cells and accumulate in lysosomes. Dead and damaged cells have ruptured lysosomes and are expected to show a decrease in the dye red fluorescence [26,27]. No reduction of acridine orange derived fluorescence intensity was observed in cells treated with $0.01 \mathrm{mg} / \mathrm{mL}$ or $0.1 \mathrm{mg} / \mathrm{mL} \mathrm{Zn-MgO} \mathrm{NPs}$ (Figure 2). Indeed, even if $(3.1 \pm 0.6) \%$ of U937 dead cells was observed after treatment with $0.1 \mathrm{mg} / \mathrm{mL}$ $\mathrm{Zn}-\mathrm{MgO}$, this cell death was not significant as untreated U937 cells already presented $(2.5 \pm 0.8) \%$ of cell mortality. HL-60 cells incubated with $0.1 \mathrm{mg} / \mathrm{mL} \mathrm{Zn-MgO}$ shown about $(17 \pm 3.1) \%$ of dead cells, while the mortality of untreated HL-60 was close to $(14 \pm 2.6) \%$, as shown in Figure 2. No significant increase in cell mortality was observed in U937 treated with $1 \mathrm{mg} / \mathrm{mL} \mathrm{Zn-MgO} \mathrm{(about} \mathrm{11 \% ),} \mathrm{while} \mathrm{HL-60}$ treated with $1 \mathrm{mg} / \mathrm{mL} \mathrm{Zn}-\mathrm{MgO}$ showed a partial cytotoxic effect because presented about $(46 \pm 6.3) \%$ dead cells. In control experiments, cells treated with $3 \% \mathrm{H}_{2} \mathrm{O}_{2}$ for 30 min were completely destroyed as shown for HL-60 cells (Figure 2). These results are in line with previous data published on $\mathrm{Zn}-\mathrm{MgO}$ cytotoxic effect on HeLa cells and macrophages that were shown to tolerate metal oxide NPs to some extent $(\leq 1 \mathrm{mg} / \mathrm{mL})[26,27]$. Probably mammalian cells are capable to phagocytose and/or digest metal oxide nanoparticles [25]. To conclude, our flow cytometry test, suggests that $\mathrm{Zn}-\mathrm{MgO}$ at concentrations below $1 \mathrm{mg} / \mathrm{mL}$ may be safely used to form an active packaging.

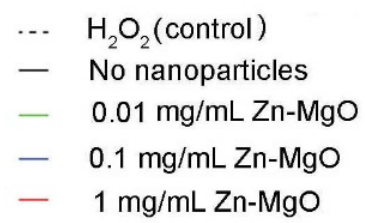

HL-60

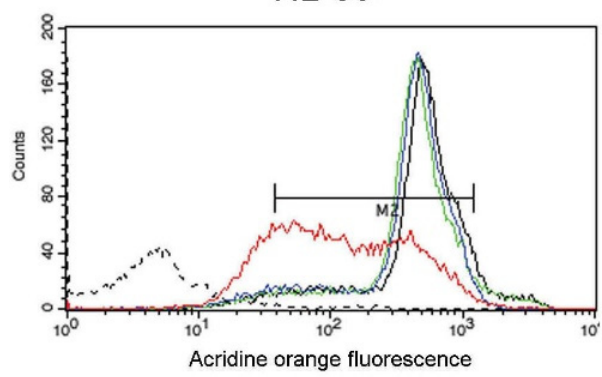

U937

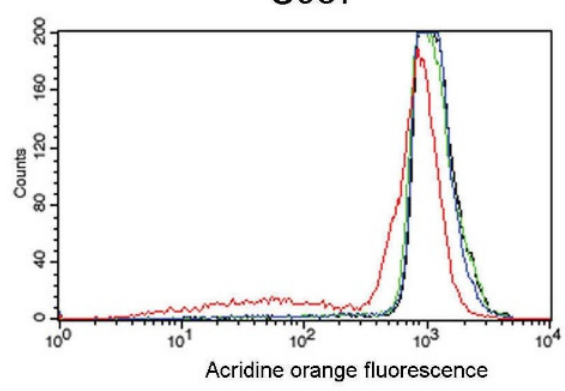

Figure 2. Viability of human monocyte U937 cells and human promyelocytic leukemia cells HL-60 incubated with various concentrations of $\mathrm{Zn}-\mathrm{MgO} \mathrm{NPs}$ for $24 \mathrm{~h}$ was estimated by acridine orange staining and flow cytometry analysis. $\mathrm{H}_{2} \mathrm{O}_{2}$ was used as a positive control as oxidative stress induces $100 \%$ mortality. 


\subsection{Challenge Test with Zn-MgO Alginate-Nanobiocomposite Active Film}

Figure 3 illustrates the working procedure in the challenge test with $\mathrm{Zn}-\mathrm{MgO}$ used as an alginate active film reinforcement. The sodium alginate, used as a packaging material to prevent the detrimental effect of oxygen on food quality, is a biodegrading film-forming biopolymer, authorized as a food additive in the EC [44]. We chose to reinforce alginate with nano-Zn-MgO NPs, because of its ability to react with various divalent and trivalent cations.

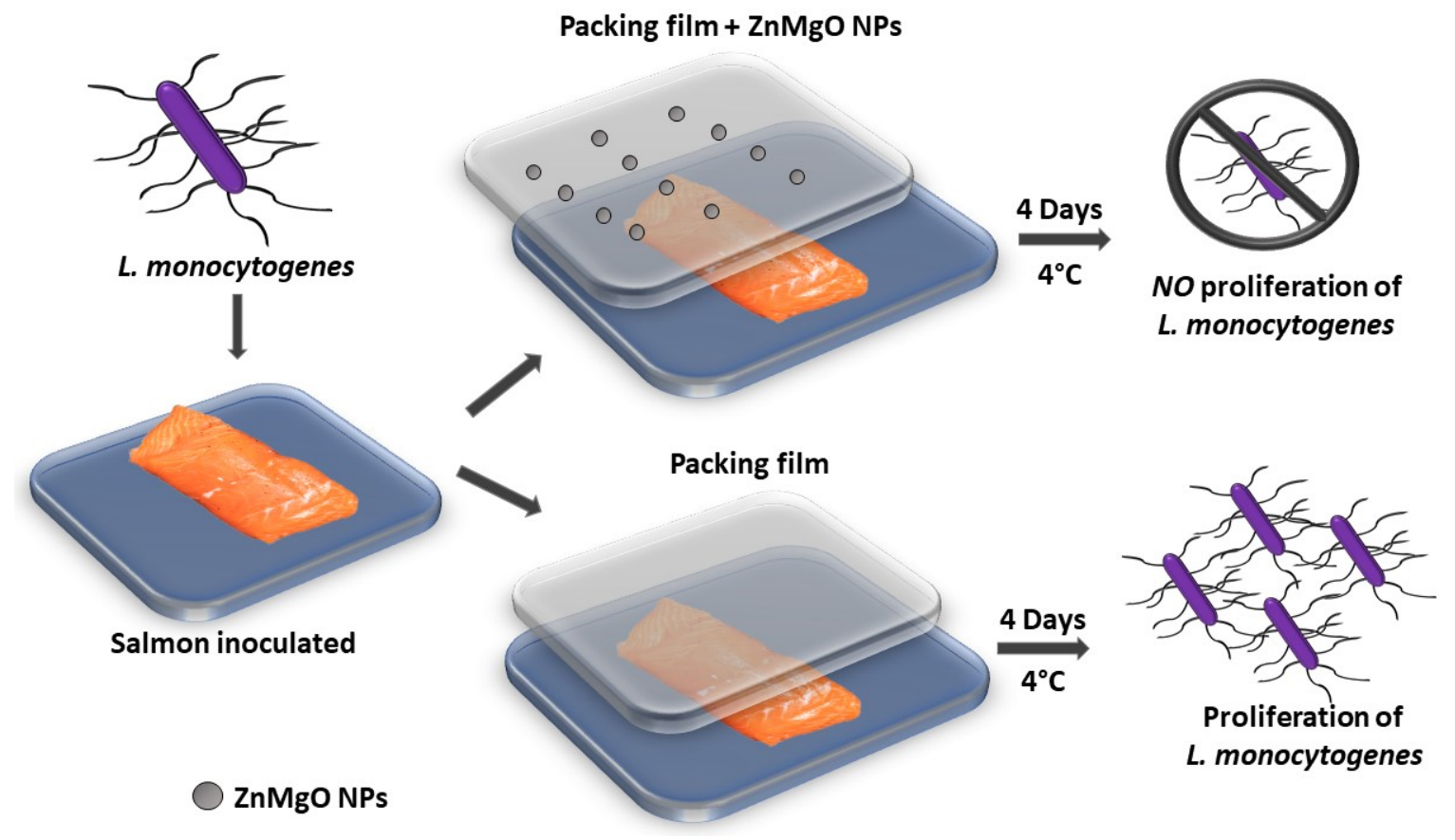

Figure 3. Description of the test conducted on cold-smoked salmon samples to verify active film effect vs. standard alginate film used for packing.

CSS samples artificially contaminated with L. monocytogenes and packed with a pure alginate film, or with the film with incorporated $\mathrm{Zn}-\mathrm{MnO} \mathrm{NPs}$ were evaluated after storage at $4{ }^{\circ} \mathrm{C}$ for 4 days. In the control smoked salmon pieces that were not inoculated, L. monocytogenes was not detected. The inoculated samples packed with the $\mathrm{Zn}-\mathrm{MgO}$-nanobiocomposite active film showed a charge of $\left(6.2 \times 10^{2} \pm 1.1 \times 10^{2}\right) \mathrm{CFU} / \mathrm{cm}^{2}$, while samples packed with the film without the addition of nanoparticles showed an increased Listeria charge value of about one $\log$, $\left(1.6 \times 10^{3} \pm 0.5 \times 10^{3}\right)$ $\mathrm{CFU} / \mathrm{cm}^{2}$. These results suggest that $1 \mathrm{mg} / \mathrm{mL}$ nano-Zn-MgO provided an antibacterial activity to alginate film. Indeed, the lower charge of L. monocytogenes observed in the samples packed with the active film suggests that it is possible to extend the shelf life of the salmon.

The efficacy of metal oxide nanoparticles as bio-preservatives in polymer-based films is probably related to film direct contact with the food surface and in that way continuous release of the particles with antimicrobial activity onto the food surfaces $[20,45,46]$. The EFSA Panel on Food Contact Materials, Enzymes, Flavourings and Processing Aids (CEF Panel) evaluated the safety of nano-ZnO only based on the migration of soluble $\mathrm{Zn}^{2+}$-ions $[7,47]$. We can, thus, presume that the observed inhibition of Listeria proliferation in CSS samples packed with $\mathrm{Zn}-\mathrm{MgO}$-nanobiocomposite originated from the diffusion of $\mathrm{Zn}^{2+}$-ions from the film to salmon meat surface. However, the solubility and diffusion of metal ions in metal oxide nanopowders integrated into polymers and aqueous solutions were shown to be low $[27,48-50]$. Taking into account that no significant cytotoxic effect towards mammalian cells of $\mathrm{Zn}-\mathrm{MgO}$ NPs at concentration $<1 \mathrm{mg} / \mathrm{mL}$ was observed, the produced active packaging could be acceptable to consumers. 
Previous studies have been reported on reinforcing natural polymers with antimicrobials (such as divergicin, nisin, potassium sorbate, sodium lactate) to produce active packaging films that suppress L. monocytogenes growth in CSS products [20,51]. It has been shown that the effectiveness of antimicrobial active films in various foods depends on the nature and concentration of the reinforcing agent used. Moreover, the polymer used may play a role. For instance, when enterocin was used to inhibit L. monocytogenes growth, its antimicrobial effects were found superior in alginate film than in zein and polyvinyl alcohol films [52]. Here, we showed that the addition of $\mathrm{Zn}-\mathrm{MgO}$ nanoparticles to the alginate film could maintain the food product at a high level of quality for a longer period.

The EC Regulation 2073/2005 on microbiological criteria for RTE foods supporting the growth of L. monocytogenes recommends the concentration limit to $100 \mathrm{CFU} / \mathrm{g}$ at the end of the shelf life $[52,53]$. $\mathrm{Zn}-\mathrm{MgO}$ NPs integrated into the biodegradable nanocomposite protecting film comply with this regulation and seem to be a good candidate for the preservation of RTE foods. However, the full validation of the $\mathrm{Zn}-\mathrm{MgO}$ NPs-alginate active packaging will involve additional tests in order to characterize its effects on the proliferation of other pathogenic microorganisms and other RTE foods.

\section{Conclusions}

We showed that $\mathrm{Zn}-\mathrm{MgO}$ NPs obtained by doping MgO crystal surface with $\mathrm{Zn}^{2+}$-ions possess improved biocompatibility together with high antibacterial activity. The packaging film obtained by the incorporation of $\mathrm{Zn}-\mathrm{MgO}$ NPs in a biodegradable alginate nanocomposite prevented L. monocytogenes proliferation in refrigerated cold-smoked salmon in contrast to the control samples that were packaged with a pure alginate film. Additional studies with sensory and safety evaluation panels should be conducted before considering the commercialization of such films.

The qPCR method described here represents a contribution to the state of the art of the quantitative methods for L. monocytogenes detection in food samples. It offers the possibility to quantify as low as $10 \mathrm{CFU} / \mathrm{g}$ of the bacterium in CSSs after an enrichment step. The primers used in this work can help to reduce the time required to detect $L$. monocytogenes in RTE foods due to the high sensitivity in qPCR. The proposed protocol is useful for food safety at the industrial level because it can help to avoid food recalls by the rapid identification of the source of CSS contamination with L. monocytogenes and control of its correct elimination from the processing chain.

Author Contributions: Conceptualization, M.M. and J.V.; validation, P.V.; formal analysis, P.V., J.V.; investigation, P.V., J.V., E.B. and V.Z.; writing—original draft preparation, M.M. and J.V.; writing—review and editing, P.V., J.V. and M.M.; visualization, P.V.; supervision, M.M. All authors have read and agreed to the published version of the manuscript.

Funding: This research received no external funding.

Acknowledgments: The University of Udine (Italy) and INRAE (Jouy en Josas, France) are acknowledged for experimental facilities. The Campus France is gratefully acknowledged for the travel support through the Galilée Grant 37184VG to MM and JV. We thank Slavica Stankic (INSP, France) for the gift of nanoparticles used in this work and Aurore Vidy (Institute Pasteur, France) for technical expertise in FACS measurements. We thank Seav-Ly Tran (INRAE, France) for critical reading of the manuscript.

Conflicts of Interest: The authors declare no conflict of interest.

\section{References}

1. Auvolat, A.; Besse, N.G. The challenge of enumerating Listeria monocytogenes in food. Food Microbiol. 2016, 53, 135-149. [CrossRef]

2. Roberts, A.; Williams, S.; Wiedmann, M.; Nightingale, K. Some Listeria monocytogenes outbreak strains demonstrate significantly reduced invasion, inlA transcript levels, and swarming motility in vitro. Appl. Environ. Microbiol. 2009, 75, 5647-5658. [CrossRef]

3. Swaminathan, B.; Gerner-Smidt, P. The epidemiology of human listeriosis. Microbes Infect. 2007, 9, $1236-1243$. [CrossRef]

4. Gandhi, M.; Chikindas, M.L. Listeria: A foodborne pathogen that knows how to survive. Int. J. Food Microbiol. 2007, 113, 1-15. [CrossRef] 
5. Liu, D.; Lawrence, M.L.; Ainsworth, A.J.; Austin, F.W. Comparative assessment of acid, alkali and salt tolerance in Listeria monocytogenes virulent and avirulent strains. FEMS Microbiol. Lett. 2005, 243, 373-378. [CrossRef] [PubMed]

6. European Food Safety Authority; European Centre for Disease Prevention and Control. The European Union Summary REPORT on trends and sources of zoonoses, zoonotic agents and food-borne outbreaks in 2012. EFSA J. 2014, 12, 3547. [CrossRef]

7. European Food Safety Authority; European Centre for Disease Prevention and Control. The European Union summary report on trends and sources of zoonoses, zoonotic agents and food-borne outbreaks in 2014. EFSA J. 2015, 13, 4329.

8. Jemmi, T.; Stephan, R. Listeria monocytogenes: Food-borne pathogen and hygiene indicator. Rev. Sci. Tech. 2006, 25, 571-580. [CrossRef]

9. Katzav, M.; Hyvoenen, P.; Muje, P.; Rantala, L.; von Wright, A. Pulsed-field gel electrophoresis typing of Listeria monocytogenes isolated in two Finnish fish farms. J. Food Protect. 2006, 69, 1443-1447. [CrossRef]

10. Garrido-Maestu, A.; Azinheiro, S.; Carvalho, J.; Prado, M. Rapid and sensitive detection of viable Listeria monocytogenes in food products by a filtration-based protocol and qPCR. Food Microbiol. 2018, 73, 254-263.

11. Välimaa, A.L.; Tilsala-Timisjärvi, A.; Virtanen, E. Rapid detection and identification methods for Listeria monocytogenes in the food chain-A review. Food Control 2015, 55, 103-114.

12. ISO. Microbiology of the Food Chain-Horizontal Method for the Detection and Enumeration of Listeria monocytogenes and of Listeria spp.-Part 2: Enumeration Method; ISO: Geneva, Switzerland, 2014.

13. ISO. Microbiology of the Food Chain-Horizontal Method for the Enumeration of Microorganisms-Part 1: Colony Count at 30 Degrees C by the Pour Plate Technique; ISO: Geneva, Switzerland, 2013.

14. Vizzini, P.; Braidot, M.; Vidic, J.; Manzano, M. Electrochemical and optical biosensors for the detection of campylobacter and listeria: An update look. Micromachines 2019, 10, 500.

15. Manzano, M.; Cocolin, L.; Cantoni, C.; Comi, G. Detection and identification ofListeria monocytogenes from milk and cheese by a single-step PCR. Mol. Biotechnol. 1997, 7, 85-88. [PubMed]

16. Omiccioli, E.; Amagliani, G.; Brandi, G.; Magnani, M. A new platform for Real-Time PCR detection of Salmonella spp., Listeria monocytogenes and Escherichia coli O157 in milk. Food Microbiol. 2009, 26, 615-622. [PubMed]

17. Vidic, J.; Manzano, M.; Chang, C.M.; Jaffrezic-Renault, N. Advanced biosensors for detection of pathogens related to livestock and poultry. Vet. Res. 2017, 48, 1-22.

18. Vidic, J.; Vizzini, P.; Manzano, M.; Kavanaugh, D.; Ramarao, N.; Zivkovic, M.; Radonic, V.; Knezevic, N.; Giouroudi, I.; Gadjanski, I. Point-of-need DNA testing for detection of foodborne pathogenic bacteria. Sensors 2019, 19, 1100.

19. Wang, Y.; Salazar, J.K. Culture-independent rapid detection methods for bacterial pathogens and toxins in food matrices. Compr. Rev. Food Sci. Food Saf. 2016, 15, 183-205.

20. Quintavalla, S.; Vicini, L. Antimicrobial food packaging in meat industry. Meat Sci. 2002, 62, 373-380.

21. Stankic, S.; Suman, S.; Haque, F.; Vidic, J. Pure and multi metal oxide nanoparticles: Synthesis, antibacterial and cytotoxic properties. J. Nanobiotechnol. 2016, 14, 1-20.

22. Vermeiren, L.; Devlieghere, F.; Debevere, J. Effectiveness of some recent antimicrobial packaging concepts. Food Addit. Contam. 2002, 19, 163-171.

23. Jones, K.E.; Patel, N.G.; Levy, M.A.; Storeygard, A.; Balk, D.; Gittleman, J.L.; Daszak, P. Global trends in emerging infectious diseases. Nature 2008, 451, 990-993.

24. Jin, T.; Sun, D.; Su, J.; Zhang, H.; Sue, H.J. Antimicrobial efficacy of zinc oxide quantum dots against Listeria monocytogenes, Salmonella enteritidis, and Escherichia coli O157: H7. J. Food Sci. 2009, 74, M46-M52. [PubMed]

25. Martínez-Carmona, M.; Gun'ko, Y.; Vallet-Regí, M. ZnO nanostructures for drug delivery and theranostic applications. Nanomaterials 2018, 8, 268.

26. Vidic, J.; Stankic, S.; Haque, F.; Ciric, D.; Le Goffic, R.; Vidy, A.; Jupille, J.; Delmas, B. Selective antibacterial effects of mixed ZnMgO nanoparticles. J. Nanoparticle Res. 2013, 15, 1595.

27. Auger, S.; Henry, C.; Péchaux, C.; Lejal, N.; Zanet, V.; Nikolic, M.V.; Manzano, M.; Vidic, J. Exploring the impact of Mg-doped $\mathrm{ZnO}$ nanoparticles on a model soil microorganism Bacillus subtilis. Ecotoxicol. Environ. Saf. 2019, 182, 109421. 
28. Auger, S.; Henry, C.; Péchoux, C.; Suman, S.; Lejal, N.; Bertho, N.; Larcher, T.; Stankic, S.; Vidic, J. Exploring multiple effects of $\mathrm{Zn} 0.15 \mathrm{Mg} 0.85 \mathrm{O}$ nanoparticles on Bacillus subtilis and macrophages. Sci. Rep. 2018, 8, 1-14.

29. Stankic, S.; Müller, M.; Diwald, O.; Sterrer, M.; Knözinger, E.; Bernardi, J. Size-dependent optical properties of $\mathrm{MgO}$ nanocubes. Angew. Chem. Int. Ed. 2005, 44, 4917-4920.

30. Corpet, F. Multiple sequence alignment with hierarchical clustering. Nucleic Acids Res. 1988, 16, 10881-10890.

31. Intergated DNA Technologies. Available online: http://eu.idtdna.com/calc/analyzer (accessed on 25 August 2020).

32. AmplifX: Manage, Test and Design Your Primers for PCR. Available online: http://crn2m.univ-mrs.fr/pub/ amplifx-dist (accessed on 25 August 2020).

33. Comi, G.; Cocolin, L.; Cantoni, C.; Manzano, M. A RE-PCR method to distinguish Listeria monocytogenes serovars. FEMS Immunol. Med. Microbiol. 1997, 18, 99-104.

34. Rohde, A.; Hammerl, J.A.; Boone, I.; Jansen, W.; Fohler, S.; Klein, G.; Dieckmann, R.; Al Dahouk, S. Overview of validated alternative methods for the detection of foodborne bacterial pathogens. Trends Food Sci. Technol. 2017, 62, 113-118.

35. Cecchini, F.; Manzano, M.; Mandabi, Y.; Perelman, E.; Marks, R.S. Chemiluminescent DNA optical fibre sensor for Brettanomyces bruxellensis detection. J. Biotechnol. 2012, 157, 25-30. [CrossRef] [PubMed]

36. Balouiri, M.; Sadiki, M.; Ibnsouda, S.K. Methods for in vitro evaluating antimicrobial activity: A review. J. Pharm. Analysis 2016, 6, 71-79. [CrossRef] [PubMed]

37. Vidic, J.; Richard, C.A.; Péchoux, C.; da Costa, B.; Bertho, N.; Mazerat, S.; Delmas, B.; Chevalier, C. Amyloid assemblies of influenza A virus PB1-F2 protein damage membrane and induce cytotoxicity. J. Biol. Chem. 2016, 291, 739-751. [CrossRef] [PubMed]

38. Akbar, A.; Anal, A.K. Zinc oxide nanoparticles loaded active packaging, a challenge study against Salmonella typhimurium and Staphylococcus aureus in ready-to-eat poultry meat. Food Control 2014, 38, 88-95. [CrossRef]

39. Gimenez, B.; Dalgaard, P. Modelling and predicting the simultaneous growth of Listeria monocytogenes and spoilage micro-organisms in cold-smoked salmon. J. Appl. Microbiol. 2004, 96, 96-109. [CrossRef]

40. Paludan-Müller, C.; Dalgaard, P.; Huss, H.H.; Gram, L. Evaluation of the role of Carnobacterium piscicola in spoilage of vacuum-and modified-atmosphere-packed cold-smoked salmon stored at $5{ }^{\circ} \mathrm{C}$. Int. J. Food Microbiol. 1998, 39, 155-166. [CrossRef]

41. Commission, E. Commission Regulation (EC) No 2073/2005 of 15 November 2005 on microbiological criteria for foodstuffs. Off. J. Eur. Union L 2005, 338, 1-26.

42. Pafundo, S.; Gulli, M.; Marmiroli, N. Multiplex real-time PCR using SYBR ${ }^{\circledR}$ GreenER ${ }^{\mathrm{TM}}$ for the detection of DNA allergens in food. Anal. Bioanal. Chem. 2010, 396, 1831-1839. [CrossRef]

43. Vieira, P.M.; Coelho, A.S.G.; Steindorff, A.S.; de Siqueira, S.J.L.; do Nascimento Silva, R.; Ulhoa, C.J. Identification of differentially expressed genes from Trichoderma harzianum during growth on cell wall of Fusarium solanias a tool for biotechnological application. BMC Genom. 2013, 14, 177. [CrossRef]

44. Bonilla, J.; Atarés, L.; Vargas, M.; Chiralt, A. Edible films and coatings to prevent the detrimental effect of oxygen on food quality: Possibilities and limitations. J. Food Eng. 2012, 110, 208-213. [CrossRef]

45. Fu, Y.; Sarkar, P.; Bhunia, A.K.; Yao, Y. Delivery systems of antimicrobial compounds to food. Trends Food Sci. Technol. 2016, 57, 165-177.

46. Ture, H.; Eroglu, E.; Ozen, B.; Soyer, F. Effect of biopolymers containing natamycin against Aspergillus niger and Penicillium roquefortii on fresh kashar cheese. Int. J. Food Sci. Technol. 2011, 46, 154-160.

47. Bolognesi, C.; Castoldi, A.F.; Crebelli, R.; Barthélémy, E.; Maurici, D.; Wölfle, D.; Volk, K.; Castle, L. Genotoxicity testing approaches for the safety assessment of substances used in food contact materials prior to their authorization in the European Union. Environ. Mol. Mutagen. 2017, 58, 361-374. [CrossRef] [PubMed]

48. Cierech, M.; Wojnarowicz, J.; Kolenda, A.; Krawczyk-Balska, A.; Prochwicz, E.; Woźniak, B.; Łojkowski, W.; Mierzwińska-Nastalska, E. Zinc oxide nanoparticles cytotoxicity and release from newly formed PMMA-ZnO nanocomposites designed for denture bases. Nanomaterials 2019, 9, 1318. [CrossRef]

49. Liu, Y.J.; He, L.L.; Mustapha, A.; Li, H.; Hu, Z.; Lin, M.S. Antibacterial activities of zinc oxide nanoparticles against Escherichia coli O157: H7. J. Appl. Microbiol. 2009, 107, 1193-1201. [CrossRef] [PubMed] 
50. Vasiljevic, Z.Z.; Dojcinovic, M.P.; Krstic, J.B.; Ribic, V.; Tadic, N.B.; Ognjanovic, M.; Auger, S.; Vidic, J.; Nikolic, M.V. Synthesis and antibacterial activity of iron manganite $\left(\mathrm{FeMnO}_{3}\right)$ particles against the environmental bacterium Bacillus subtilis. RSC Adv. 2020, 10, 13879-13888. [CrossRef]

51. Benabbou, R.; Subirade, M.; Desbiens, M.; Fliss, I. The impact of chitosan-divergicin film on growth of Listeria monocytogenes in cold-smoked salmon. Front. Microbiol. 2018, 9, 2824. [CrossRef]

52. Marcos, B.; Aymerich, T.; Monfort, J.M.; Garriga, M. Use of antimicrobial biodegradable packaging to control Listeria monocytogenes during storage of cooked ham. Int. J. Food Microbiol. 2007, 120, 152-158. [CrossRef]

53. Beaufort, A.; Bergis, H.; Lardeux, A.; Lombard, B. EURL Lm TECHNICAL GUIDANCE DOCUMENT for conducting shelf-life studies on Listeria monocytogenes in ready-to-eat foods. Appl. Environ. Microbiol. 2014, $74,594-604$.

(C) 2020 by the authors. Licensee MDPI, Basel, Switzerland. This article is an open access article distributed under the terms and conditions of the Creative Commons Attribution (CC BY) license (http://creativecommons.org/licenses/by/4.0/). 